\title{
Impact of neem coated urea on rice yield and nutrient use efficiency (NUE)
}

\author{
Arshdeep Singh*, Anita Jaswal and Maninder Singh \\ Department of Agronomy, School of Agriculture, \\ Lovely Professional University, Phagwara-144 411, Punjab, India. \\ Received: 16-06-2018 \\ Accepted: 13-03-2019
}

DOI: $10.18805 /$ ag.R-1817

\begin{abstract}
Neem coated urea not only increase crop yield but also lower input cost to the farmer. Cost of neem coated urea is only 3$4 \%$ higher than ordinary urea. Urea constitutes about $82 \%$ of the fertilizer nitrogen $(\mathrm{N})$ used in India. Neem coated urea has been observed to improve nitrogen use efficiency and subsequently crop yield, especially in rice and wheat. Nitrification inhibitors when applied along with urea reduce losses of applied $\mathrm{N}$ thereby resulting in an improved yield of crops. In rice and wheat more than $50 \%$ of the urea consumed in India is applied, the mean increase in grain yield by replacing urea with $\mathrm{NCU}$ or NOCU is 5 to $6 \%$. More than 75 studies have been conducted to compare the performance of urea coated with neem cake (NCU) or neem oil (NOCU) in increasing the yield of rice, wheat, and several other crops via uncoated urea. In 2015, the Government of India directed that all fertilizer urea manufactured in the country or imported will have to be coated with neem oil at the rate of $0.5 \mathrm{~kg}$ per tonne. This decision was motivated not only by the better performance of NOCU via uncoated urea but also by an expectation that it will lead to reduced consumption of urea. Increasing nitrogen efficiency means-reducing the nitrogen losses through leaching, immobilization and reducing groundwater pollution by nitrates as well as ammonia gas pollution in the air. It also reduces import of costly fertilizers as well as reduces ground, water, and soil pollution.
\end{abstract}

Key words: Immobilization, Leaching, Neem coated urea, Neem oil coated urea, Nutrient use efficiency.

Rice (Oryza sativa) is the major staple food for most of Asia including India. Among cereal crops, it serves as a principal source of nourishment for half of the world's population. India is the second largest producer of rice after China. The world's total production of rice is 70\% in India and the rest of it produced in Pakistan. In our country, Punjab, Haryana, U.P, Uttrakhand, J \& K are major states of rice production. In fact, Punjab is not a rice producing state but now rice is the main Kharif crop of the state. Up to 1965, the northeast part of Punjab was 7.25 lakh ha under cultivation of paddy (Tanwar, 2014). The average yield was 6 quintal per acre, and production was 43.5 lakh quintals. In Asia, India has the largest area under rice $(43.4 \mathrm{~m} \mathrm{ha})$ accounting for $29.4 \%$ of the global rice area and recorded in terms of production (104.3 million tons) with average productivity of $2137 \mathrm{~kg} \mathrm{ha}^{-1}$ during 2015-16. Like this, there is an increase in production from four to forty times in the last 50 years. Due to this change, Punjab is known as 'rice bowl' of India. The total area under cultivation and production in India was 27 lakh hectare and 81 lakh tonne of which the area and production in Punjab was 8.62 lakh hectare and 25.30 lakh tonne, respectively (Kumar et al., 2012).

$\mathrm{N}$ is an essential plant nutrient being a major constituent of amino acids, nucleic acids, nucleotides, chlorophyll, enzymes, and hormones. $\mathrm{N}$ increased the vegetative growth of the plant and increased grain yield and grain quality by the formation of more tillers, leaf area development, and formation of grains, grain filling, and protein synthesis. Nitrogen is required in huge amounts for rice and supply of $\mathrm{N}$ in the right amount, at the right rate and at right time throughout the growing season is most important to increase the yield. With the $\mathrm{N}$ application, there was an increase in $40 \%$ in per capita of food production from 50 years (Smil, 2002). To fulfill the requirement of $50 \%$ of food production is dependent on nitrogen fertilizer (Ladha et al., 2005). Around 120 million metric tons of nitrogenous fertilizer is required in each year to meet the demand for Nitrogen for crop growth (Kumar et al., 2010).

Rice-wheat (RW) cropping system is the main cropping system being practiced 85 percent of the cultivated area in Punjab. The main source of $\mathrm{N}$ in this region is urea by which $\mathrm{N}$ requirement of the crop is fulfilled. Due to heavy losses of $\mathrm{N}$ because of leaching and denitrification nitrogen use efficiency (NUE) is very low (30-50\%), to meet the demand of $\mathrm{N}$ farmer needs to apply a huge amount of nitrogen fertilizer in agricultural crops. According to Singh et al., (2003), in a rice-wheat cropping system, N use/recovery efficiency rarely exceeds $30-40$ percent. By 2050, nitrogen fertilization is expected to increase by 2.7 times on a global scale (Thind et al., 2010). If the rate of fertilizers provided

*Corresponding author's e-mail address: harrydeep628@gmail.com

Vill. Nibber wind, P.O Mattewal, Teh. Baba Bakala, Amritsar-143 119, Punjab, India. 
to the crops regularly increasing it leads to showing the worst effects on the crops and ultimately followed the law of diminishing returns. The efficiency of urea is a major problem both in direct seeded and transplanted rice. Nitrogen is applied to the crop in split doses at various growth stages from transplanting to flowering stage.

Furthermore, during the application of slow release fertilizer the loss of nitrogen is reduced (Joshi et al., 2014). In India, this is the traditional method to mix the urea with neem cake to increase the nitrogen use efficiency (Agostini, 2010). Urea is coated by neem oil and reduces the $\mathrm{N}$ losses and $\mathrm{N}$ is slowly released to crop throughout its life cycle (Singh et al., 2003). Although it had been established long ago that neem products, when applied along with urea can enhance NUE in crops (Khandey et al., 2017). Therefore, research investigations based on scientifically-sound experiments and published in peer-reviewed journals have been critically analyzed to better understand the agronomic benefits of neem coated urea as compared to ordinary urea.

Need for controlled fertilizers: Controlled or slow-release fertilizers have been developed to overcome the demerits of ordinary urea. Urea dissolved in soil within 7-10 days after its application. As we know $\mathrm{N}$ plays important role in vegetative growth of plant. Most of Urea applied at the time of planting when $\mathrm{N}$ utilized by the crop is very less so most of the applied urea is wasted whereas at vegetative growth stage when the demand of nutrient is more the crop suffered mostly by nutrient stress. Controlled release fertilizer (CRF) is developed which-releases nutrients in slow manner and provided to the crop throughout the life cycle (Shivay et al., 2000). The widespread agriculturally important slow or controlled release fertilizers are coated urea such as sulphur coated urea (SCU), neem coated urea (NCU) and polymercoated urea, nitrification inhibitors, and urease inhibitor etc. The shelf life of ordinary urea is improved with the coatings of different emulsions and helps to retain urea in the field for a long time to increase the yield and improve the crop qualities (Prasad et al., 2007).

What is neem coated urea?: Neem oil is extracted from seeds of neem (Azadirachta indica) contains melicians (generally known as neem bitters) of which Epinimbin, Diacetyl and Azadirachtin are the main fractions, which are responsible for nitrification inhibition action (Devakumar 2016). Neem (Azadirachta indica) is a tall perennial tree. The fruits are shed during May-July. Seeds are collected and used for extracting oil. The manure is prepared from the cake which is left after extraction and used for making neem cake-coated urea.

The neem nitrification inhibiting properties and its phenomenon in increasing NUE in rice were first reported by Naresh et al., 2003. With the ethanol extract of neem seeds urea was treated. Scientists at the Indian Agricultural
Research Institute (IARI), New Delhi (India) found the nitrification-inhibiting properties of neem (Rao et al., 2000) and neem-cake coated urea (Pushpanathan et al., 2005). This has been accepted by the farmers. Scientists at IARI have also experimented with neem oil and a urea - neem oil product (10 per- cents by weight of urea) and found superior to prilled urea for rice (Desai et al., 2014). The use of neem coated urea has been found to improve the uptake of N, P and $\mathrm{K}$ significantly.

Why neem coat is required?: Soil fertility is determined by three major elements namely nitrogen, phosphorus \& potassium $(\mathrm{N}, \mathrm{P}, \mathrm{K})$ of which nitrogen plays a very important role. For this reason, urea (containing $46 \%$ of $\mathrm{N}$ ) consumption is very high all over the world. Unfortunately, more than half (up to 60\%) of the nitrogen leaches out or vaporizes in the form of nitrogen gas, ammonia, and nitrous oxide due to the presence of denitrifying bacteria in the soil.

\section{Featured benefits of neem coated urea}

1. Slow down the process of nitrification of urea.

2. Neem Coated Urea reported improved yield up to $48 \%$,

3. Decrease urea requirement by $50 \%$ and

4. Controls soil born nematodes, termites and another pest due to pesticide properties.

Why use neem coated urea?: The positively charged ammonium-N cations are retained by negatively charged soil colloids and are less prone to leaching and denitrification losses as compared to the nitrate-N anions (Murthy et al., 2013). The nitrates formed after nitrification of nitrogen are liable to be leached down or denitrified if not utilized by the plants. But the submerged (anaerobic) conditions in lowland rice favor significant losses of $\mathrm{N}$ in nitrous oxide $\left(\mathrm{N}_{2} \mathrm{O}\right)$ and dinitrogen $\left(\mathrm{N}_{2}\right)$ forms (Denitrification). Hence, $\mathrm{N}$ should be in the ammonium form for a fairly long time to avoid its losses by denitrification (Khandey et al., 2017). Coating urea granules with one of several forms of neem (natural oil from Azadirachta indica) to produce neem coated urea (NCU) delayed nitrification or have other slow-release properties that will allow it to better feed plant needs, thereby improving $\mathrm{N}$-use efficiency and reducing nitrous oxide emission. NCU often improves grain yield of rice and wheat (compared with uncoated urea) but does not consistently reduce $\mathrm{N}_{2} \mathrm{O}$ emissions or improve N-use efficiency. Split application of urea treated with neem extract coated may improve the grain yield and $\mathrm{N}$ use efficiency due to minimizing the release rate.

The urea application timing is appeared to be more effective for increasing $\mathrm{N}$ use efficiency in rice .Basal application of the whole amount of neem extract coated urea was beneficial for growth and yield of rice (Singh et al., 2006) and on the other hand observed that neem extract coated urea applied in split produced significantly higher grain yield than its whole amount was given as basal. 
Neem coated urea via vs. normal urea:

(a) Effect of neem coated urea (NCU) on growth characters of rice: Coated fertilizers and using $\mathrm{N}$ inhibitors are the form of fertilizers releasing the nitrogen slowly thereby efficient and maximum utilization of nitrogen is possible. Resulted neem coated fertilizers improved the yield components like productive tillers, panicle length, fertile spikelet's per panicle and 1000 grain weight when applied at a proper time have been reported (Pushpanathan et al., (2005). Singh et al., (2006) studied that the modifications in fertilizer source and/or management can lead to reduced losses of $\mathrm{N}$, high wheat yields and increased fertilizer N-use efficiency. Performance of neem coated urea @ $96 \mathrm{~kg} \mathrm{~N} \mathrm{ha}^{-1}$ drilled during sowing of wheat was better than neem-coated urea applied @ $120 \mathrm{~kg} \mathrm{~N} \mathrm{ha}^{-1}$ in 2 split doses at Ludhiana. This study suggests that neem- coated urea can lead to improved $\mathrm{N}$-use efficiency when applied either in 3 split doses or drilled between rows as a single dose in coarsetextured soils rather than in fine-textured soil. Nitrogen may be applied through neem coated urea @ $100 \mathrm{~kg} \mathrm{ha}^{-1}$ in 3 splits doses i.e. at basal, 25 and 45 DAS. This application was found more productive and profitable (Joshi et al., 2014). Among all types of urea, neem coated urea was best which increase the growth and yield, plant height, a number of tillers $\mathrm{m}^{-2}$, numbers of panicle hill ${ }^{-1}$, numbers of grains panicle ${ }^{-1}$ and dry matter accumulation $\mathrm{m}^{-2}$ of rice (Kumar et al., 2015).

(b) Effect of neem coated urea (NCU) on rice yield: The coating urea with neem oil, neem cake or neem oil microemulsion improved rice growth and resulted in more grain and straw yield than commercial prilled urea (Kashiri Habib ollah 2013). Neem coated urea gave significantly higher grain yield and increased the nitrogen use efficiency as compared to prilled urea. Yield decreased if $\mathrm{N}$ rate was reduced from the recommended rate (Khanna et al., 2000). Upadhyay and Tripathi (2000) studied that response of prilled and neem extract coated urea application timings to rice (Oryza sativa). The application of neem extract coated urea (NCU) $50 \%$ basal, $25 \%$ at tillering $+25 \%$ at panicle initiation (PI) stage recorded the maximum grain and straw yield. The application of $30 \%$ NCU as basal + prilled urea (PU) $40 \%$ at tillering and $30 \%$ at PI stage or NCU $75 \%$ basal and $25 \%$ at PI stage performed as good as application of NCU $50 \%$ basal $+25 \%$ at tillering $+25 \%$ at PI stage for grain yield, $\mathrm{N}$ concentration and $\mathrm{N}$ uptake of rice. Neem oil coating has shown its superiority in enhancing the $\mathrm{N}$ use efficiency, grain yield, $\mathrm{N}$ concentration in grain of wheat crop in all tested soils (Suganya et al., 2007). Nitrogen management through neem coated urea and application method further improve rice productivity using different doses of NCU and prilled urea and resulted that the yield was higher when NCU was used in comparison to PU (Sarangi et al. 2016). It implied that simply the basal application-till one week after transplanting proved an effective $\mathrm{N}$ management strategy resulting in an increase in yield. (c) Effect of neem coated urea with manures and fertilizers on yield: Sanjay et al., 2015 studied that the effect of different organic manures and fertilizers on yield and nutrient uptake of maize (Zea mays L.) using three organic manures viz., FYM, vermicompost and poultry manure with fertilizers and neem coated urea. The results indicated neem coated urea significantly increased nutrient availability and uptake. Application of $100 \%$ recommended dose of nitrogen through neem coated urea (4 ml neem oil/100 g urea) significantly increased both grain and straw yield over all treatments. To evaluate Application of different sources of nitrogen on the yield of wheat the results revealed that the maximum grain yield $42.40 \mathrm{q} \mathrm{ha}^{-1}$ was recorded in $100 \% \mathrm{~N}$ through NCU followed by $100 \% \mathrm{~N}$ through urea $37.37 \mathrm{q} \mathrm{ha}^{-1}$ and $80 \% \mathrm{~N}$ through NCU $35.36 \mathrm{q} /$ ha over farmer practice, which has recorded minimum grain yield $34.77 \mathrm{q} \mathrm{ha}^{-1}$ (Mangat et al., 2004).

(d) Effect of neem coated urea (NCU) on nutrient uptake: Due to the addition of neem coated urea as a nitrification inhibitor in the soil resulted in higher uptake of $\mathrm{N}\left(\mathrm{NH}_{4}^{+} \mathrm{N}\right.$ availability) by rice and better utilization for grain production. Suresh et al., 2008 studied that the effect of slow released fertilizers, biogas slurry and BGA on yield, uptake and N-use efficiency in rice. Application of slow-release fertilizers, biogas slurry, and BGA significantly increased grain and straw yield, nitrogen uptake, nitrogen use efficiency and nitrogen recovery in rice. Nitrogen availability and uptake as influenced by time of application and $\mathrm{N}$ sources. Available $\mathrm{N}$ in the soil increased up-to panicle initiation stage and then started declining as the growth advanced. Among the sources, neem cake blended urea maintained high available $\mathrm{N}$ status in the soil at all phonological stages compared to other slow release forms of urea (Rajan et al., 2012). With regard to different $\mathrm{N}$ source, neem cake blended urea recorded the highest uptake and prilled urea recorded the lowest uptake at all the phenological stages. The highest grain yield was recorded in neem cake blended urea applied in four equal splits. The study conclusively proved that the physical blending of urea in four equal splits enhanced the $\mathrm{N}$ availability, $\mathrm{N}$ uptake, and productivity in semi-dry rice (Krishanamurthy et al., 2010). The balanced nutrition led to better uptake of all the nutrients. With regard to different $\mathrm{N}$ source, neem cake blended urea recorded the highest uptake and prilled urea recorded the lowest uptake. Upadhyay and Tripathi (2000), (Kumar et al., 2011) and Kumar et al. (2007) also found superiority of NCU over ordinary urea in $\mathrm{N}$ uptake and nitrogen use efficiencies.

(e) Effect of neem coated urea (NCU) on nitrogen use efficiency: $\mathrm{N}$ use efficiency and percentage apparent recovery of fertilizer were greatest with $50 \mathrm{~kg} \mathrm{~N}$ applied as urea blended with neem cake (Suganya et al., 2009). Suri et al., 2004 worked in the coating of prilled urea with eco- 
friendly neem resulted significantly increased the number of effective tillers hill ${ }^{-1}$, panicle length, panicle weight, grain and straw yields and nitrogen uptake, thereby revealing a significant decline in agronomic nitrogen use efficiency (NUE). Indicated that coated urea with neem formulations increased the grain yield, NUE and apparent $\mathrm{N}$ recovery (Shivay et al., 2001).

(f) Effect of neem coated urea on enzyme activity: Shivay et al., 2000 studied that influence of neem products on urease activity, urea transformation in soils and wheat yield. Resulted in higher concentration of $\mathrm{NH}_{3}-\mathrm{N}$ was recorded in prilled urea treatment than the other treatments of neem products at the tillering stage, however, the concentration of $\mathrm{NH}_{3}-\mathrm{N}$ decreased at booting and harvesting stage of the crop. There was a slow transformation of $\mathrm{NO}_{2}-\mathrm{N}$ in neem (products) coated treatments, and neem oil proved superior to the other products. The urease activity was significantly lower in treatments having neem products as compared to prilled urea. Neem oil coating has shown its superiority in enhancing the $\mathrm{N}$ use efficiency, grain yield. Urease activity was significantly reduced under NOCU compared to the PU (Murthy et al., 2015). At all the stages, neem oil coated urea (NOCU) showed significantly lower gaseous loss of $\mathrm{NH}_{3}$ as well as different $\mathrm{N}$-fractions in the soil compared to $\mathrm{PU}$ indicating that neem oil inhibited both ammonification and nitrification. Neem oil coated urea was found to persist for a longer duration than PU in soil and supply $\mathrm{N}$ needs of the plant more effectively (Khandey et al., 2017). (g) Effect of neem coated urea on leaching and mineralization: Smil (2002) studied that neem for sustainable agriculture and the environment. Because of its bactericidal properties it has been reported that neem inhibit nitrification gives higher grain yield and fertilizer nitrogen use efficiency. NCU reduces nitrate leaching to groundwater and ammonia and nitrous oxide emissions to the environment. Datt et al. (2007) studied that nitrogen mineralization and relative efficiency of neem and neem coated urea for wheat and rice. Resulted in $100 \%$ neem coated urea produce more grain and straw yield both in rice (9.2\% and $6.8 \%$ higher yield) and wheat crop. The N, P, and $\mathrm{K}$ uptake higher in neem coated urea over urea similar trend as yield. A slight build-up of available nitrogen status was observed in neem coated urea treatment than urea after the harvest both rice and wheat. Neem coated urea supply the nutrient to the plant and reduced the losses of $\mathrm{N}$ in soil (Kumar et al., 2010).

\section{CONCLUSION}

Neem coated urea or oil coated urea always providing slow release nitrogen to crops. The nitrification and $\mathrm{N}$ losses are reduced. The nutrient use efficiency is increased in field crops where the coated urea is used as a comparison to untreated urea. In India, in case of rice and wheat more than $50 \%$ of the urea is consumed but it is replaced by the coated urea and help to enhance nutrient use efficiency. Slow releasing fertilizers provide the great result of crop production and also proving good fertility and productivity level.

\section{REFERENCES}

Agostini, F., Tei, F., Silgram, M., Farneselli, M., Benincasa, P. and Aller, M.F., (2010). Decreasing nitrate leaching in vegetable crops with better N management. In Genetic engineering, biofertilisation, soil quality and organic farming (147-200). Springer, Dordrecht.

Datt, N., Sharma, R.P., Paliyal, S.S., Singh, G., Parmar, D.K., Sankhyan, N.K. and Chander, G., (2007). Nitrogen Mineralisation Studies and Relative Efficiency of Urea and Neem Coated Urea for Wheat-Rice. Indian Journal of Fertilisers, 3(8): 51.

Desai, M.K., Usadadiya, V.P., Thanki, J.D., Patel, K.G. and Arvadia, K., (2014). Growth, yield and quality of Bt cotton (G. Hirsutum) as influenced by nitrogen application under South Gujarat condition. Int. J. Agric. Innov. Res, 2: 871-873.

Devakumar, C., (2016). Evolution of neem oil coated urea through frugal innovation. Indian Journal of Fertilisers, 12(4): $120-125$.

Joshi, A., Gupta, J.K., Choudhary, S.K. and Paliwal, D.K., (2014). Efficiency of different nitrogen source, doses and split application on growth and yield of maize (Zea mays L.) in the Malwa region of Madhya Pradesh. IOSR J. Agric. Veter. Sci, 7(2): $2319-2372$.

Kashmiri, H.O., (2013). Improving nitrogen-use efficiency through essential oils' coated prilled urea in aerobic rice (Oryza sativa L.)wheat (Triticum aestivum L.) cropping system (Doctoral dissertation, IARI, DIVISION OF AGRONOMY).

Khandey, N., (2017). Evaluation of neem coated urea and prilled urea on rice yield and nutrient use efficiency (nue) in vertisol of CG (Doctoral Dissertation, Indira Gandhi Krishi Vishwavidyalaya, Raipur).

Khanna, P., Pandey, N. and Tripathi, R.S., (2000). Relative performance of soil: FYM conditioned and neem based product coated urea on grain yield and N-use efficiency of transplanted rice in vertisols. Agricultural Science Digest, 20(4): 259-260.

Krishnamurthy, P., Sreedevi, B., Ram, T., Padmavathi, G., Kumar, R.M., Rao, P.R., Rani, N.S., Latha, P.C. and Singh, S.P., (2010) Evaluation of rice genotypes for phosphorus use efficiency under soil mineral stress conditions. ORYZA-An International Journal on Rice, 47(1): 29-33.

Kumar, D., Devakumar, C., Kumar, R., Das, A., Panneerselvam, P. and Shivay, Y.S., (2010). Effect of neem-oil coated prilled urea with varying thickness of neem-oil coating and nitrogen rates on productivity and nitrogen-use efficiency of lowland irrigated rice under Indo-Gangetic plains. Journal of plant nutrition, 33(13): 1939-1959.

Kumar, D., Devakumar, C., Kumar, R., Das, A., Panneerselvam, P. and Shivay, Y.S., (2010). Effect of neem-oil coated prilled urea with varying thickness of neem-oil coating and nitrogen rates on productivity and nitrogen-use efficiency of lowland irrigated rice under Indo-Gangetic plains. Journal of plant nutrition, 33(13): 1939-1959. 
Kumar, D., Devakumar, C., Kumar, R., Panneerselvam, P., Das, A. and Shivay, Y.S., (2011). Relative efficiency of prilled urea coated with major neem (Azadirachta indica A. Juss) oil components in lowland irrigated rice of the Indo-Gangetic plains. Archives of Agronomy and Soil Science, 57(1): 61-74.

Kumar, N., Prasad, R. and Zaman, F.U., (2007). Relative response of high yielding variety and a hybrid of rice to levels and sources of nitrogen. Proceedings- Indian National Science Academy, 73(1),1.

Kumar, R., Devakumar, C., Kumar, R. and Gupta, A.K., (2012). A simple and robust method for determination of neem (Azadirachta indica A. Juss) oil in neem oil coated urea. Toxicological \& Environmental Chemistry, 94(4): 641-649.

Kumar, R., Jaiswal, P., Kumar, A. and Kumar, S., (2015). Effect of modified urea on nitrogen use efficiency, growth and yield of transplanted rice (Oryza sativa L.) var. NDR-359. New Agriculturist, 26: 263-266.

Ladha, J.K., Pathak, H., Krupnik, T.J., Six, J. and van Kessel, C., (2005). Efficiency of fertilizer nitrogen in cereal production: retrospects and prospects. Advances in Agronomy, 87: 85-156.

Mangat, G.S., 2004. Research Note: Relative Efficiency of NFL-Neem coated urea and urea for rice. Fertiliser News, 49(2): 63-66.

Murthy, K.D., Rao, A.U., Vijay, D. and Sridhar, T.V., (2015). Effect of levels of nitrogen, phosphorus and potassium on performance of rice. Indian Journal of Agricultural Research, 49(1): 83-87.

Murthy, K.D., Rao, A.U., Vijay, D. and Sridhar, T.V., (2015). Effect of levels of nitrogen, phosphorus and potassium on performance of rice. Indian Journal of Agricultural Research, 49(1): 83-87.

Naresh, M., (2003). Effect of biogas slurry and neem oil-treated urea sources on rice (Oryza sativa)-wheat (Triticum aestivum) cropping system. Indian Journal of Agronomy, 48(2): 73-77.

Prasad, R., Shivay, Y.S. and Kumar, D., (2017). Current status, challenges, and opportunities in rice production. In Rice Production Worldwide (pp. 1-32). Springer, Cham.

Pushpanathan, K.R., Vijayakumar, M. and Siddeswaran, K., (2005). Effect of forms of fertilizer nitrogen and timing of application on growth and yield of rice (Oryza sativa 1.). Agriculture Review, 2:153-156.

Rajan, B., (2012). Relative performance of neem coated urea viz-a-viz ordinary urea applied to rice-wheat cropping in sub-tropical soils. Asian Journal of Soil Science, 7(2): 353-357.

Rao, G.G.E., Thimmegowda, S., Chalapathi, M.V., Kumar, N.D., Prakash, J.C. and Mallikarjuna, K., (2000). Relative efficiency of nimin coated and prilled urea in lowland rice under different irrigation regimes. Environment and Ecology, 18(1):49-52.

Sanjay Kumar, V.V., Vageesh, T.S., Abhiram, G.J. and Shilpashree, Y.P., (2015). Effect of compost enriched with NPK fertilizers and neem oil coated urea on productivity and nutrient use efficiency in maize. Karnataka J. Agric. Sci, 28(2): 185-188.

Sarangi, S.K., Maji, B., Singh, S., Srivastava, A.K., Singh, U.S. and Sharma, D.K., (2016). Nitrogen management through neem coated urea and application method further improve rice productivity in coastal flood-prone rainfed lowland. In $4^{\text {th }}$ International Agronomy Congress New Delhi . 2: 22-26

Shivay, Y.S., Prasad, R. and Singh, S., (2000), February. Effect of nitrogen levels and neem oil emulsions coated urea on growth, yield attributes and yield of wetland rice. In Extended summary of International Conference on Managing Natural Resources (14-18).

Shivay, Y.S., Prasad, R., Singh, S. and Sharma, S.N., (2001). Coating of prilled urea with neem (Azadirachta indica) for efficient nitrogen use in lowland transplanted rice (Oryza sativa). Indian Journal of Agronomy, 46(3): 453-457.

Singh, A.K., Ram, H., Maurya, B.R. and Prasad, J., 2006. Research Note: Influence of Neem Products on Urease Activity, Urea Transformation in Soils and Wheat Yield. Indian Journal of Fertilisers 2(2): 45.

Singh, B. and Kumar, A., (2003). Effect of slow release fertilizers, biogas slurry and BGA on yield, uptake and N-use efficiency in rice. Journal of Farm Science, 12:146-147.

Singh, S. and Shivay, Y.S., (2003). Coating of prilled urea with ecofriendly neem (Azadirachta indica A. Juss.) formulations for efficient nitrogen use in hybrid rice. Acta agronomica hungarica, 51(1): 53-59.

Smil, V., (2002). Nitrogen and food production: proteins for human diets. AMBIO: A Journal of the Human Environment, 31(2), pp.126-131.

Suganya, S., Appavu, K. and Vadivel, A., (2007). Nitrogen release pattern of neem coated urea products in floodwater. Asian Journal of Soil Science, 2(2): 128-133.

Suganya, S., Appavu, K. and Vadivel, A., (2007). Relative efficiency of neem coated urea products for rice grown in different soils. Asian Journal of Soil Science, 2(2): 29-34.

Suresh, S. and Piria, R.S., (2008). Studies on the bio-efficacy of neem coated urea on rice. Asian Journal of Soil Science, 3(2): 333-335.

Suri, I.K., Prasad, R. and Devakumar, C., (2004). Neem coating of urea-present status and future trends. Fertiliser News, 49(8): 21-24.

Tanwar, V.S., (2014). Effect of different organic manures and fertilizers on yield and nutrient uptake of maize (Zea mays L.). Asian Journal of Science and Technology, 5(12): 905-908.

Thind, H.S., Pannu, R.P.S., Gupta, R.K., Vashistha, M., Singh, J. and Kumar, A., (2010). Relative performance of neem (Azadirachta indica) coated urea vis-a-vis ordinary urea applied to rice on the basis of soil test or following need based nitrogen management using leaf colour chart. Nutrient cycling in agroecosystems, 87(1): 1-8.

Upadhyay, S.K. and Tripathi, R.S.,(2000). Response of prilled and neem extract coated urea application timings to rice (Oryza sativa). Agric. Sci. Digest, 20(2): 84-86. 